University of Nebraska - Lincoln

DigitalCommons@University of Nebraska - Lincoln

Publications, Agencies and Staff of the U.S.

Department of Commerce

U.S. Department of Commerce

2011

\title{
Movements of two satellite-tagged pygmy killer whales (Feresa attenuata) off the island of Hawai'i
}

\author{
Robin W. Baird \\ Cascadia Research Collective, rwbaird@cascadiaresearch.org \\ Gregory S. Schorr \\ Cascadia Research Collective \\ Daniel L. Webster \\ Cascadia Research Collective \\ Dan J. McSweeney \\ Wild Whale Research Foundation \\ M. Bradley Hanson \\ NOAA Fisheries
}

See next page for additional authors

Follow this and additional works at: https://digitalcommons.unl.edu/usdeptcommercepub

Part of the Environmental Sciences Commons

Baird, Robin W.; Schorr, Gregory S.; Webster, Daniel L.; McSweeney, Dan J.; Hanson, M. Bradley; and Andrews, Russel D., "Movements of two satellite-tagged pygmy killer whales (Feresa attenuata) off the island of Hawai'i" (2011). Publications, Agencies and Staff of the U.S. Department of Commerce. 229. https://digitalcommons.unl.edu/usdeptcommercepub/229

This Article is brought to you for free and open access by the U.S. Department of Commerce at DigitalCommons@University of Nebraska - Lincoln. It has been accepted for inclusion in Publications, Agencies and Staff of the U.S. Department of Commerce by an authorized administrator of DigitalCommons@University of Nebraska - Lincoln. 


\section{Authors}

Robin W. Baird, Gregory S. Schorr, Daniel L. Webster, Dan J. McSweeney, M. Bradley Hanson, and Russel D. Andrews 


\title{
Notes
}

MARINE MAMMAL SCIENCE, 27(4): E332-E337 (October 2011)

2011 by the Society for Marine Mammalogy

Published 2011. This article is a US Government work and is in the public domain in the USA.

DOI: $10.1111 /$ j.1748-7692.2010.00458.x

\section{Movements of two satellite-tagged pygmy killer whales (Feresa attenuata) off the island of Hawai' $i$}

ROBIN W. BAIRD

GREGORY S. SCHORR

DANIEL L. WeBSTER

Cascadia Research Collective, $218 \frac{1}{2}$ W. 4th Avenue,

Olympia, Washington 98501, U.S.A.

E-mail: rwbaird@cascadiaresearch.org

DAN J. MCSWEENEY

Wild Whale Research Foundation, P. O. Box 139, Holualoa, Hawaii 96725, U.S.A.

\author{
M. BRAdLEy HaNSON \\ Northwest Fisheries Science Center, \\ NOAA Fisheries, \\ 2725 Montlake Boulevard East, \\ Seattle, Washington 98112, U.S.A. \\ Russel D. ANDrews \\ Alaska SeaLife Center, \\ 301 Railway Avenue, \\ Seward, Alaska 99664, U.S.A. \\ and \\ School of Fisheries and Ocean Sciences, \\ University of Alaska Fairbanks, \\ Fairbanks, Alaska 99709, U.S.A.
}

Pygmy killer whales (Feresa attenuata) are a rare tropical oceanic odontocete that are normally found close to shore only around oceanic islands (Donahue and Perryman 2009, McSweeney et al. 2009). In the Exclusive Economic Zone (EEZ) surrounding the Hawaiian Islands there is a single stock of pygmy killer whales recognized (Carretta et al. 2010). In the Hawaiian EEZ they are the third-least abundant of the 12 species of delphinids documented, with an estimated abundance of 956 individuals $(\mathrm{CV}=0.83$; Barlow 2006). Around the island of Hawai' $\mathrm{i}$ a long-term 
photo-identification study has identified a small population that exhibits high site fidelity (McSweeney et al. 2009). This species is encountered only infrequently (an average of once every $35 \mathrm{~d}$ on the water), and thus limited information is available to examine movements based on location records of photo-identified individuals. Only a small number of identification photos have been available from other islands in the main Hawaiian Islands so there has been little ability to assess movements among islands.

As part of a long-term research effort to examine odontocete movements, habitat use, ecology, and abundance (Baird et al. 2008, 2009, 2010), we remotely deployed two dorsal fin attached satellite tags on pygmy killer whales off the island of Hawai ' $\mathrm{i}$ in 2008 and 2009, and report here on movements and habitat use of these two individuals. Given the accumulating evidence of multiple discrete populations of other, better studied, species of odontocetes around the main Hawaiian Islands (Chivers et al. 2007, 2010; Baird et al. 2008, 2009; Andrews et al. 2010; Courbis et $a l .{ }^{1}$ ), information on movements of pygmy killer whales is relevant to assessing whether multiple stocks of this species also exist within the Hawaiian EEZ. While the sample size is small, because of the low encounter rate and the usual difficulty in approaching individuals close enough for tagging, it is unlikely we will be able to obtain additional movement data from this species any time soon. Information from the two tags represents the only information available on movements for this species and greatly increases information on habitat use.

The satellite tags were a small location-only SPOT5 tag (Wildlife Computers, Inc., Redmond, WA) in the Low Impact Minimally Percutaneous External-electronics Transmitter (LIMPET) configuration (Andrews et al. 2008, Schorr et al. 2009, Baird et al. 2010) with attachment darts that penetrated $4.5 \mathrm{~cm}$ into the dorsal fin. The tags were attached using a pneumatic rifle from a distance of $2.5-6 \mathrm{~m}$. Based on predicted satellite overpasses and taking into account the potential battery life and attachment duration, the tag deployed in 2008 was set to transmit $15 \mathrm{~h} / \mathrm{d}$ for periods from 2 to $4 \mathrm{~h}$ in duration with intervals between transmission periods ranging from 1 to $3 \mathrm{~h}$. The tag deployed in 2009 was set to transmit $13 \mathrm{~h} / \mathrm{d}$ for periods from 2 to $3 \mathrm{~h}$ with intervals from 1 to $4 \mathrm{~h}$ between transmission periods. Tagged whales and other individuals in the group were photo-identified and matched to a longterm photo-identification catalog (see McSweeney et al. 2009) to determine sighting history. Age class (adult, subadult) was estimated in the field based on body size relative to other individuals.

Data obtained from the Argos system was processed with the Douglas Argos-Filter v. 7.06 (available at http://Alaska.usgs.gov/science/biology/spatial/douglas.html, accessed January 2009) using two independent methods: distance between consecutive locations, and rate and bearings among consecutive movement vectors. Each location is assigned a "location class" by Argos, which reflects the estimated precision of the location, with the most precise locations being classes 3 and 2. We set the Douglas Argos-Filter to automatically retain location classes 3 and 2. Maximum rate of movement was set at $10 \mathrm{~km} / \mathrm{h}$. Depth and distance from shore for all locations which

\footnotetext{
${ }^{1}$ Unpublished data from S. Courbis, Biology Department, Portland State University, P.O. Box 751, Portland, OR.
} 
Table 1. Percentage of locations of different Argos location classes by individual pygmy killer whale.

\begin{tabular}{lcc}
\hline \hline & \multicolumn{2}{c}{ Individual } \\
\cline { 2 - 3 } Argos location class & HIFa398 & HIFa279 \\
\hline 3 & 5.8 & 5.8 \\
2 & 21.1 & 14.4 \\
1 & 20.2 & 37.6 \\
0 & 13.5 & 23.1 \\
A & 20.2 & 11.0 \\
B & 19.2 & 8.1 \\
\hline
\end{tabular}

passed the Douglas Argos-filter were determined in ArcGIS v. 9.2 (ESRI, Redlands, $\mathrm{CA}$ ) using a $50 \times 50 \mathrm{~m}$ multibeam synthesis bathymetry model from the Hawai' $\mathrm{i}$ Mapping Research Group (available at http://www.soest.hawaii.edu/HMRG/ multibeam/index.php, accessed June 2008). Rates of horizontal movements were calculated using the time and distance between pairs of consecutive locations obtained from 1 to $6 \mathrm{~h}$ apart. Shorter and longer intervals between locations were not used to reduce positive and negative biases associated with the variability in Argos location accuracy and reversals in movement direction, respectively. Minimum straight-line distance (i.e., not taking into account potential intervening land masses) from the tagging locations were calculated for all points.

A subadult-sized pygmy killer whale (HIFa398 in our catalog) was tagged on 6 December 2008. The individual had not been previously documented in our photoidentification catalog although the group that it was in (12 individuals) contained seven individuals that had been previously documented. An adult-sized pygmy killer whale (HIFa279 in our catalog) was tagged on 8 April 2009. This individual had first been documented in our photo-identification catalog in January 2007 and had been seen on eight occasions prior to tagging (including at the time HIFa398 was tagged). HIFa398 was also present in the group when HIFa279 was tagged. For HIFa398, 104 locations that passed the filter were received over the $11 \mathrm{~d}$ span of signal contact (Table 1). Seven locations for HIFa398 plotted on land. For HIFa279, no locations were received for the first $2 \mathrm{~d}$ after tagging, but after that 173 locations that passed the filter were received over a $20 \mathrm{~d}$ span (Table 1). Fifteen locations from HIFa279 plotted on land. Given the steep slope of the bathymetry in the areas where most of the locations were received and the close proximity to shore in general (see below), locations that plotted on land were used in travel speed calculations.

Both individuals remained strongly associated with the island of Hawai' $i$ over the period that signals were received from the tags (Fig. 1). Median distance from shore was $4.07 \mathrm{~km}$ for HIFa398 (range $=0.03-14.08 \mathrm{~km}$ ) and $4.66 \mathrm{~km}$ for HIFa279 (range $0.05-19.9 \mathrm{~km}$ ). Both individuals moved out of the study area of McSweeney et al. (2009) around the south point of the island and along the southeast coast of the island (Fig. 1). HIFa398 remained south of the location where it was tagged over the $11 \mathrm{~d}$ period, moving a maximum straight line distance away from the tagging location of about $106 \mathrm{~km}$, although HIFa398 reversed course back towards 


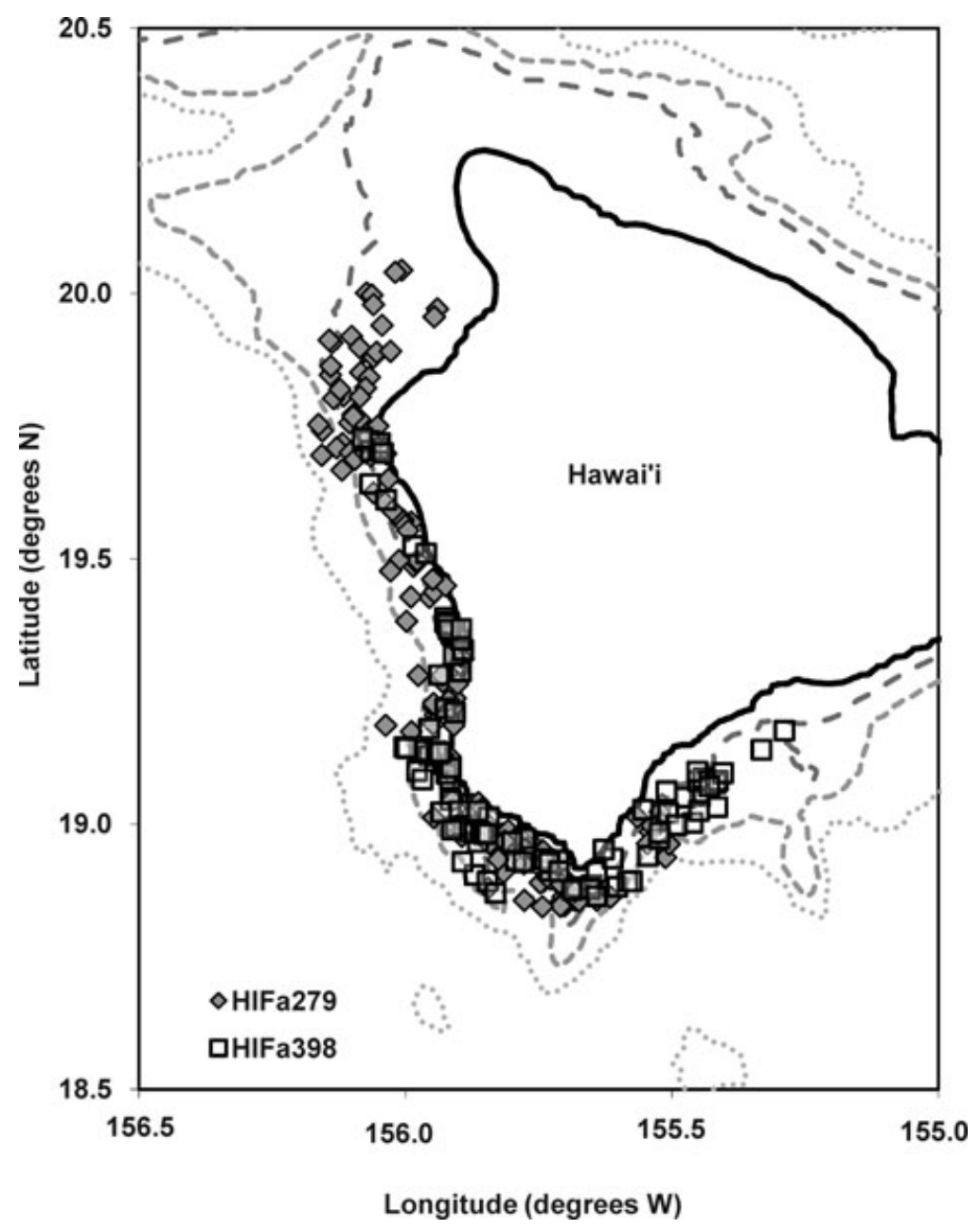

Figure 1. Map of the island of Hawai $i$ showing filtered locations of two satellite-tagged pygmy killer whales. The $1,000 \mathrm{~m}, 2,000 \mathrm{~m}$, and 3,000 $\mathrm{m}$ depth contours are shown.

the tagging location on several occasions (Fig. 2). HIFa279 moved a maximum straight-line distance of $79 \mathrm{~km}$ from the tagging location, spending time both south and north of the tagging location and repeatedly reversing direction (Fig. 2). Median depth of locations was $1,093 \mathrm{~m}$ for HIFa398 (range $=6-2,270 \mathrm{~m}$ ) compared to $977 \mathrm{~m}$ for HIFa279 (range $=8-2,842 \mathrm{~m}$ ). The shallowest depths recorded should be taken with caution given the steep slope of the bathymetry and known error associated with Argos satellite locations.

Median travel speed was $3.1 \mathrm{~km} / \mathrm{h}$ for HIFa398 ( $n=73$ intervals) and $2.7 \mathrm{~km} / \mathrm{h}$ for HIFa279 ( $n=112$ intervals). There is one report in the literature of supposed pygmy killer whales traveling at $30 \mathrm{~km} / \mathrm{h}$ (Castro 2004), however photographic documentation from that sighting indicates the group seen were false killer whales (Pseudorca crassidens) rather than pygmy killer whales (Baird 2010). Median travel 


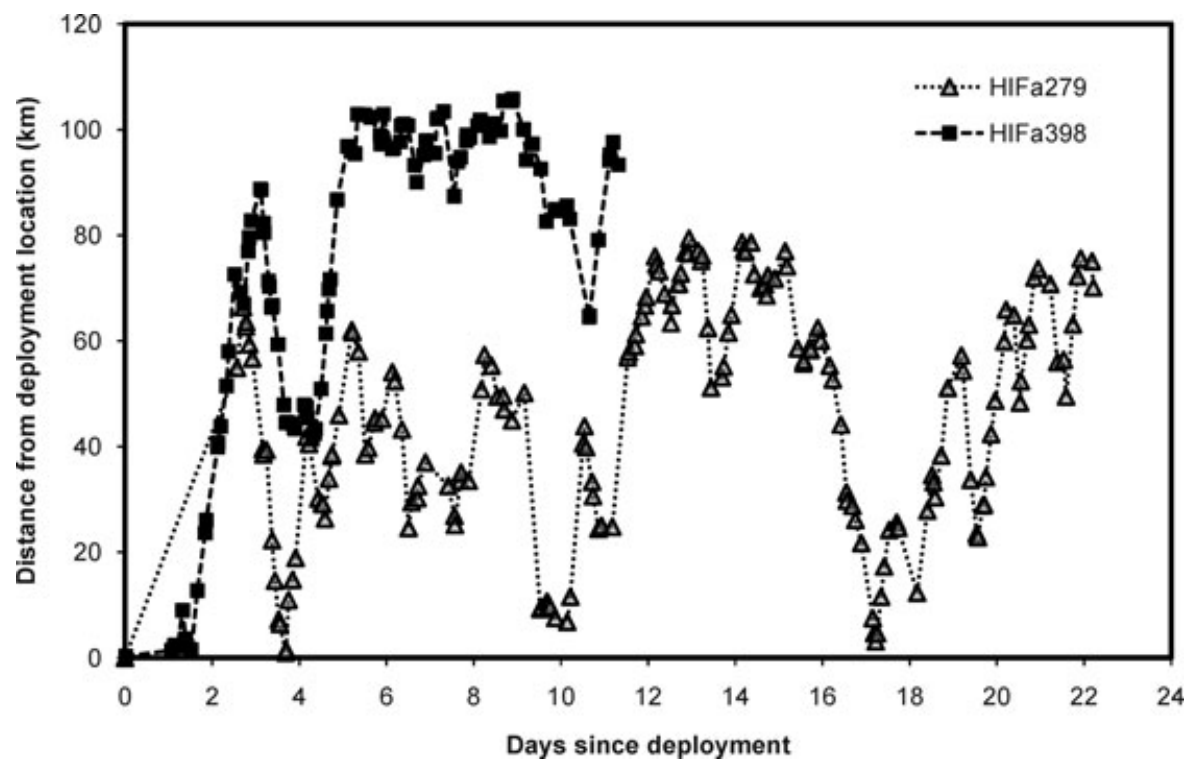

Figure 2. Straight-line distance from the tagging location over time for two pygmy killer whales. HIFa398 remained south of the tagging location for the duration of signal contact while HIFa279 moved south of the tagging location for the first $3 \mathrm{~d}$ then north until day 10 , south again until day 17 , north for approximately $1 \mathrm{~d}$, and then remained south of the tagging location for the rest of signal contact. Note the greatest distances are negatively biased when the individuals were along the southeast coast of the island (see Fig. 1).

speeds documented were lower than has been documented for satellite tagged false killer whales (Baird et al. 2010) or melon-headed whales (Peponocephala electra; Schorr et al. ${ }^{2}$ ).

Although our sample size is small, just two individuals tracked over 10 and $22 \mathrm{~d}$, this represents the first information on movements available for this species. McSweeney et al. (2009) had noted that high resighting rates of photo-identified individuals indicated a small island-associated population, with individuals repeatedly documented in the area for up to $21 \mathrm{yr}$. That the two tagged whales remained strongly associated with the island for the period that we have locations corroborates this, providing further evidence that these individuals may be resident to the island and that there may be multiple stocks within the Hawaiian EEZ, rather than a single stock as currently recognized (Carretta et al. 2010). Given the relatively short duration of the present observations, more data (e.g., population genetics) is needed to confirm this hypothesis.

\section{ACKNOWLEDGMENTS}

Funding for field work was provided by the U.S. Navy (N45) via the Southwest Fisheries Science Center of NOAA Fisheries and the Naval Postgraduate School. Funding for satellite

\footnotetext{
${ }^{2}$ Unpublished data from G. S. Schorr, Cascadia Research Collective, 218 1/2 W. 4th Avenue, Olympia, WA.
} 
tags was provided by Dolphin Quest. We thank Masa Ushioda and Deron Verbeck for providing identification photos of both individuals, Sabre Mahaffy for matching tagged whales and their companions to our photo-identification catalog, Damon Holzer for GIS processing of the location data, and Joe Mobley and two anonymous reviewers for helpful comments on the manuscript. Research was undertaken under NMFS Scientific Research Permit No. 731-1774 issued to RWB.

\section{LITERATURE Cited}

Andrews, R. D., R. L. Pitman and L. T. Ballance. 2008. Satellite tracking reveals distinct movement patterns for Type B and Type C killer whales in the southern Ross Sea, Antarctica. Polar Biology 31:1461-1468.

Andrews, K. R., L. Karczmarski, W. W. L. Au, et al. 2010. Rolling stones and stable homes: Social structure, habitat diversity and population genetics of the Hawaiian spinner dolphin (Stenella longirostris). Molecular Ecology 19:732-748.

Baird, R. W. 2010. Pygmy killer whales (Feresa attenuata) or false killer whales (Pseudorca crassidens)? Identification of a group of small cetaceans seen off Ecuador in 2003. Aquatic Mammals 36:326-327.

Baird, R. W., D. L. Webster, S. D. Mahaffy, D. J. McSweeney, G. S. Schorr and A. D. Ligon. 2008. Site fidelity and association patterns in a deep-water dolphin: Roughtoothed dolphins (Steno bredanensis) in the Hawaiian archipelago. Marine Mammal Science 24:535-553.

Baird, R. W., A. M. Gorgone, D. J. McSweeney, et al. 2009. Population structure of islandassociated dolphins: Evidence from photo-identification of common bottlenose dolphins (Tursiops truncatus) in the main Hawaiian Islands. Marine Mammal Science 25:251-274.

Baird, R. W., G. S. Schorr, D. L. Webster, D. J. McSweeney, M. B. Hanson and R. D. Andrews. 2010. Movements and habitat use of satellite-tagged false killer whales around the main Hawaiian Islands. Endangered Species Research 10:107-121.

Barlow, J. 2006. Cetacean abundance in Hawaiian waters estimated from a summer/fall survey in 2002. Marine Mammal Science 22:446-464.

Carretta, J. V., K. A. Forney, M. S. Lowry, et al. 2010. U.S. Pacific marine mammal stock assessments: 2009. NOAA Technical Memorandum NMFS-SWFSC-453. 336 pp.

Castro, C. 2004. Encounter with a school of pygmy killer whales (Feresa attenuata) in Ecuador, southeast tropical Pacific. Aquatic Mammals 30:441-444.

Chivers, S. J., R. W. Baird, D. J. McSweeney, D. L. Webster, N. M. Hedrick and J. C. Salinas. 2007. Genetic variation and evidence for population structure in eastern North Pacific false killer whales (Pseudorca crassidens). Canadian Journal of Zoology 85:783-794.

Chivers, S. J., R. W. Baird, K. M. Martien, et al. 2010. Evidence of genetic differentiation for Hawai' $i$ insular false killer whales (Pseudorca crassidens). NOAA Technical Memorandum NMFS-SWFSC-458. 46 pp.

Donahue, M. A., and W. L. Perryman. 2009. Pygmy killer whale Feresa attenuata. Pages 938 939 in W. F. Perrin, B. Würsig and J. G. M. Thewissen, eds. Encyclopedia of marine mammals. Academic Press, San Diego, CA.

McSweeney, D. J., R. W. Baird, S. D. Mahaffy, D. L. Webster and G. S. Schorr. 2009. Site fidelity and association patterns of a rare species: Pygmy killer whales (Feresa attenuata) in the main Hawaiian Islands. Marine Mammal Science 25:557-572.

Schorr, G. S., R. W. Baird, M. B. Hanson, D. L. Webster, D. J. McSweeney and R. D. Andrews. 2009. Movements of satellite-tagged Blainville's beaked whales off the island of Hawai'i. Endangered Species Research 10:203-213.

Received: 21 September 2010

Accepted: 19 November 2010 